\title{
Analysis and modelling of the factors controlling seed oil concentration in sunflower: a review
}

\author{
Fety Nambinina Andrianasolo ${ }^{1,2}$, Philippe Debaeke ${ }^{2,3, \star}$, Luc Champolivier ${ }^{1}$ and Pierre Maury ${ }^{3,4}$ \\ 1 Terres Inovia, Centre INRA de Toulouse, CS 52627, 31326 Castanet-Tolosan, France \\ 2 INRA, UMR 1248 AGIR, CS 52627, 31326 Castanet-Tolosan, France \\ 3 Université de Toulouse, INPT, UMR AGIR, 31029 Toulouse, France \\ 4 Université de Toulouse, INPT-ENSAT, UMR 1248 AGIR, CS 52627, 31326 Castanet-Tolosan, France
}

Received 4 November 2015 - Accepted 15 January 2016

\begin{abstract}
Sunflower appears as a potentially highly competitive crop, thanks to the diversification of its market and the richness of its oil. However, seed oil concentration (OC) - a commercial criterion for crushing industry - is subjected to genotypic and environmental effects that make it sometimes hardly predictable. It is assumed that more understanding of oil physiology combined with the use of crop models should permit to improve prediction and management of grain quality for various end-users. Main effects of temperature, water, nitrogen, plant density and fungal diseases were reviewed in this paper. Current generic and specific crop models which simulate oil concentration were found to be empirical and to lack of proper evaluation processes. Recently two modeling approaches integrating ecophysiological knowledge were developed by Andrianasolo (2014, Statistical and dynamic modelling of sunflower (Helianthus annuus L.) grain composition as a function of agronomic and environmental factors, Ph.D. Thesis, INP Toulouse): (i) a statistical approach relating OC to a range of explanatory variables (potential OC, temperature, water and nitrogen stress indices, intercepted radiation, plant density) which resulted in prediction quality from 1.9 to 2.5 oil points depending on the nature of the models; (ii) a dynamic approach, based on "source-sink" relationships involving leaves, stems, receptacles (as sources) and hulls, proteins and oil (as sinks) and using priority rules for carbon and nitrogen allocation. The latter model reproduced dynamic patterns of all source and sink components faithfully, but tended to overestimate OC. A better description of photosynthesis and nitrogen uptake, as well as genotypic parameters is expected to improve its performance.
\end{abstract}

Keywords: Seed oil concentration / sunflower / genotype / crop management / crop model

Résumé - Analyse et modélisation des facteurs contrôlant la teneur en huile chez le tournesol. Le tournesol apparaît comme une culture potentiellement compétitive grâce à la diversité de ses débouchés et de la richesse en huile de ses graines. Cependant, la teneur en huile de la graine $(\mathrm{TH})$ - critère commercial pour la trituration - dépend d'effets génotypiques et environnementaux ce qui en complexifie parfois la prédiction. Nous faisons l'hypothèse qu'une meilleure compréhension de la physiologie de l'accumulation d'huile combinée à l'utilisation de modèles de culture permettrait d'améliorer la prédiction et la gestion de la qualité du grain pour différents usages. Les principaux effets de la température, de l'eau, de l'azote, de la densité de peuplement et des maladies fongiques sont revus dans cette synthèse. Les modèles de culture génériques et spécifiques apparaissent empiriques pour ce qui concerne TH et manquent d'évaluation pour ce critère. Récemment, deux approches de modélisation intégrant des connaissances écophysiologiques ont été développées par Andrianasolo (2014, Modélisation statistique et dynamique de la composition de la graine de tournesol (Helianthus annuus L.) sous l'influence des facteurs agronomiques et environnementaux, Ph.D. Thesis, INP Toulouse) : (i) une approche statistique reliant la teneur en huile à une gamme de variables explicatives (TH potentielle, température, indices de stress eau et azote, rayonnement intercepté, densité de peuplement) dont la qualité prédictive est de 1.9 à 2.5 points d'huile selon le type de modèle développé ; (ii) une approche dynamique basée sur les relations 'source-puits' incluant les feuilles, les tiges, les réceptacles (en tant que sources), les coques, les protéines et l'huile (en tant que puits) et mobilisant des règles de priorité pour l'allocation du carbone et de l'azote. Ce modèle reproduit assez bien les dynamiques des composantes « sources » et «puits » avec une tendance à surestimer TH.

^ Correspondence: debaeke@toulouse.inra.fr 
Une meilleure prise en compte de la photosynthèse et de l'absorption d'azote mais aussi des paramètres génotypiques est nécessaire à l'amélioration des performances d'un tel modèle dynamique.

Mots clés : Teneur en huile des grains / tournesol / génotype / conduite de culture / modèle de culture

\section{Introduction}

Sunflower (Helianthus annuus L.) crop is mainly cultivated for its seeds (achenes) rich in oil used for human food (salad oil, frying oil, ready meals...) and non-food outlets (biofuels, green chemistry...) (Borredon et al., 2011; Jouffret et al., 2011). Oil concentration (OC) of sunflower seeds (44\% in average) is higher than oilseed rape OC (40\%) and far higher than soybean OC (18\%) (Prolea, 2009). The other constituents of sunflower achene are proteins (18\%), cellulose (15\%), water $(9 \%)$, carbohydrates and minerals (14\%) (Prolea, 2009; Roche, 2005). The achene can be separated in two parts: the hull or pericarp, which represents between 20 and $40 \%$ of achene weight (Connor and Hall, 1997; Lindström et al., 2007) and the kernel. The black hull is mainly composed of lignin and cellulose with low protein (4\%) and lipid (5\%) content (Cancalon, 1971; Knowles, 1978). The kernel is composed of a coat, an endosperm, and the embryo where 95-97\% of the achene oil is found with storage proteins (Izquierdo et al., 2008). Oil is extracted from the achene through crushing process after no or partial dehulling. Oil and protein cakes (used for animal feeding) represent more than $90 \%$ of the outlets of sunflower seeds. The other marketable uses are bird feed and confectionary (Borredon et al., 2011).

Sunflower oil ranks in 4th position at world level $(8 \%$ of $186 \mathrm{Mt}$ oil in 2012) after palm (29\%), soybean (22\%) and oilseed rape (13\%). Russia, Ukraine (both 53\%, 7.9 Mt), UE-27 (19\%, $2.7 \mathrm{Mt})$ and Argentina (10\%, 1.5 Mt) are the four largest sunflower oil producers in the world accounting for $82 \%$ of global volume (Prolea, 2012).

According to FAO (2014), oil and cakes demand will continue increasing in the future. In France, the potential development of biodiesel has stimulated the research on sunflower since 2005 in a context of limiting resources (water, fossil energy, inputs... ) (Pilorgé, 2010). However, contrary to oilseed rape, sunflower seeds are not currently used by industry for biofuels. Climate change will obviously open new opportunities for sunflower cultivation (i) as the crop has moderate requirements in irrigation water, (ii) as a C3 plant it could benefit from $\mathrm{CO}_{2}$ fertilization in the future and (iii) because cropping area could move towards northern regions in Europe (Tuck et al., 2006). In addition, more plant protein is required for fulfilling the world demand in animal protein which should double at 2050 horizon if food systems do not change (FAO, 2014); sunflower cakes could contribute to this increasing demand.

In Europe, sunflower oil ranks at $2 \mathrm{nd}$ position $(23 \%, 3.4 \mathrm{Mt}$ in 2012) after oilseed rape (59\%, $8.7 \mathrm{Mt})$ and before soybean (11\%, 1.7 Mt) (Prolea, 2012). France is the first sunflower oil producer (550.000 $\mathrm{t}$ in 2012) in Europe followed by Spain (482.000 t), Hungary (390.000 t) and Romania (339.000 t) (Prolea, 2012). The highest grain yields are reached in France $\left(2.4\right.$ t.ha $\left.^{-1}\right)$ with a strong inter-annual variability (from 1.9 to 2.9 t.ha $^{-1}$ between 1989 and 2014) (Agreste, 2015). As grain yields are rather stable but at a low level, as sunflower growing areas are stagnating or decreasing in some major countries, increasing oil concentration has to be achieved to meet oil production requirements.

Seed oil concentration is often expressed as percentage of grain dry mass in the literature. However, in France, a commercial standard of $44 \%$ oil, $9 \%$ water and $2 \%$ impurities has been fixed by the oil crushing industry and most of the results are expressed according to this standard. This has to be carefully checked when comparing results from different sources. The grain cooperatives are submitted to premiums and penalties when selling their production to crushers. Only in a few cases, the farmers are paid according to the oil concentration of the seeds they deliver to the cooperative. Most of the time, the premium in case of OC exceeding $44 \%$ is shared among farmers whatever their contribution to global grain quality. This results from the technical difficulty to measure routinely OC at harvest delivery (Champolivier, Debaeke, Thibierge, 2011). Contrary to protein or oleic acid concentrations, no indirect method (for instance Near Infra-Red Spectroscopy, NIRS) is available for measuring rapidly and accurately OC on intact seeds at the elevator level (Merrien et al., 2010).

In France, two oil quality profiles are produced and distributed on the market: conventional oil (rich in linoleic acid, omega 6 ) on $44 \%$ of the cultivated area; oleic oil ( $>82 \%$ of oleic acid, omega 9) on 56\% of the area (Terres Inovia, 2015). Minor oil components such as tocopherols and phytosterols confer some additional value for human health (Berger et al., 2010).

Understanding of OC elaboration and effects of genotype and environmental factors raised to be essential for the development of crop modelling tools in order to propose convenient management strategies targeting both grain yield and oil concentration in sunflower (Aguirrezabal et al., 2015). After reporting the most determining factors of OC in sunflower, this paper presents a review of the different ways to predict OC as a function of genotype, environment and management in sunflower.

\section{Variability of oil concentration (OC) in time and space}

In France (2001-2012), oil production fluctuated between $528.000 \mathrm{t}$ and $644.000 \mathrm{t}$ according to inter-annual variations in sunflower-sown areas, grain yields and oil concentrations (Prolea, 2012). Meanwhile actual grain yield did not progress with the same rate than genetic improvement (Jouffret et al., 2011; Vear et al., 2003). Yield-limiting factors have been characterized and their impact on grain yield and OC have been quantified (Champolivier, Debaeke, Thibierge, 2011; Quere, 2004): water stress due to summer drought, fungal diseases during grain filling, low and uneven plant population, and soil compaction. Most of the limiting factors of yield 


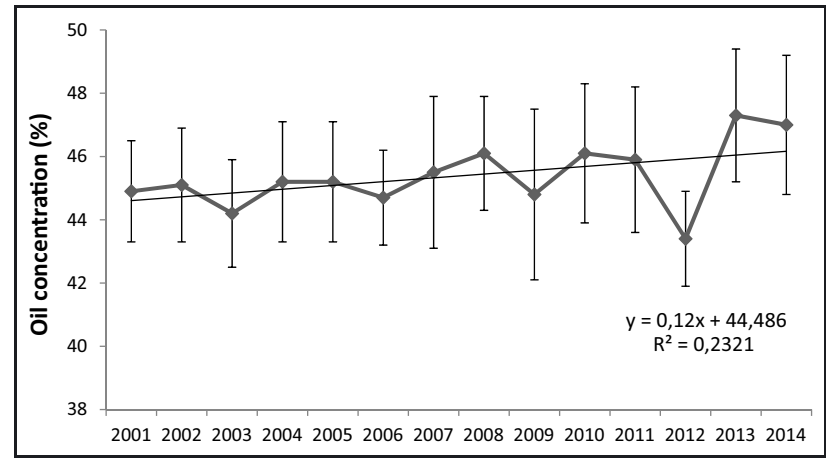

Fig. 1. Changes in seed oil concentration in sunflower at French level from 2001 to 2014 (from Terres Inovia at http://www.terresinovia.fr). Error bars correspond to standard deviation.

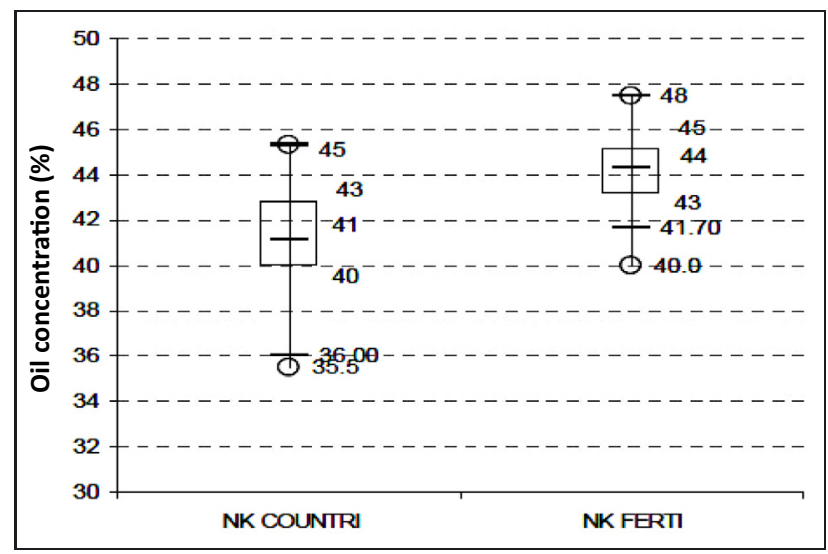

Fig. 2. Comparison of seed oil concentration variability (OC, \%, at commercial standard) for two sunflower cultivars in SW France (2009) (from Champolivier, Debaeke, Thibierge, 2011).

will affect also oil accumulation during grain filling; therefore yield and OC are globally related for a given cultivar (Piva et al., 2000).

Since 1993, Cetiom (now Terres Inovia) and Onidol (now Terres Univia) have conducted an observatory of grain quality at national and regional level. This survey indicated that oil concentration might change drastically from one year to another: e.g. $47.3 \%$ in 2013 versus $43.4 \%$ in 2012 (Fig. 1). This inter-annual variation has to be related to changes in varietal landscape and to climatic conditions during summer. The apparent trend of increasing OC with time should be confirmed in the future.

Champolivier, Debaeke, Thibierge (2011) conducted an agronomic survey in two production areas of South-Western France from 2007 to 2009. By comparing two cultivars with contrasting potential OC, they observed that $\mathrm{OC}$ variability due to environment (E) (soil, climate, crop management) was greater than variability due to genotype $(\mathrm{G})$ : about 10 points of oil for E vs. 5 points of oil for G (Fig. 2). As for grain yield, a wide range of responses in $\mathrm{OC}$ was observed. Knowing a variety and its potential OC (as given by the pre- and postregistration variety tests, see MyVar from Terres Inovia: www. myvar.com) is an indication useful for the cooperative but it doesn't guarantee an attainable level of grain quality.
Currently, the main strategy used by grain cooperatives to increase $\mathrm{OC}$ is to recommend cultivars with high OC to growers. Nevertheless, other strategies could be suggested, for example a better adjustment of the $\mathrm{N}$ fertilization. Champolivier et al. (2004) concluded to a higher gross margin for farmers when fitting $\mathrm{N}$ fertilization to plant requirements while cooperatives made more profit when recommending rich-oil cultivars. However, in this simulation-based study, a lower potential yield was assumed for the varieties rich in oil. Contrary to protein concentration in cereals, a negative correlation between grain yield and OC is not the rule in oilseed crops (in spite of more energy required for lipogenesis than for starch accumulation).

Therefore to improve variety choice and related crop management, more information is required on the drivers of oil accumulation and final $\mathrm{OC}$ in production basins as well as simulation models to predict $\mathrm{OC}$ according to various cultivars and management strategies. For that purpose, some basic physiological knowledge is required to better understand how and when determining factors influence oil content.

\section{Physiology of oil accumulation}

\subsection{Fatty acids biosynthesis}

Oil in sunflower is essentially located in grains and is composed of $98 \%$ triacylglycerols (TAG), the remaining part being free fatty acids, phospholipids and unsaponifiable fraction (Echarte et al., 2010). Chains of saturated (palmitic and stearic) and unsaturated (oleic) fatty acids are obtained from a series of carboxylation and hydrolysis processes that take place in the plasts. Fatty acids are then exported to the cytoplasm where they are transformed into triacylglycerols. Linoleic acid is obtained from the desaturation of oleic acid in the endoplasmic reticulum. TAG are stored into closed vesicles called oleosomes (Berger et al., 2010; Roche, 2005).

\subsection{Oil accumulation dynamics}

Oil accumulation in grains begins from R5.1 stage (Schneiter and Miller, 1981) and stops soon before or at physiological maturity (Chervet and Vear, 1989). Dynamics of oil concentration follows a sigmoid pattern (Fig. 3) (Champolivier and Merrien, 1996): from 7 to 10 days after the onset of flowering (Mantese et al., 2006), oil accumulation rate is low and is only due to incorporation of polar lipids into membranes. Then, oil accumulation rate increases linearly during 200 to 250 degree days (base temperature of $6{ }^{\circ} \mathrm{C}$ ) before reaching a plateau at circa 30th day after the end of flowering. Such plateau is related to the phase during which oil amount accumulates at a low but similar rate as other grain components (Merrien, 1992).

Accumulation starts in peripherical achenes and follows the same centripetal pattern as flowering on the sunflower capitulum. It is often reported that external achenes are richer in oil than central ones (Merrien, 1992). Some authors evoked default of vascular connections in the central zone (Goffner et al., 1988) while others suggested consequences of competition 


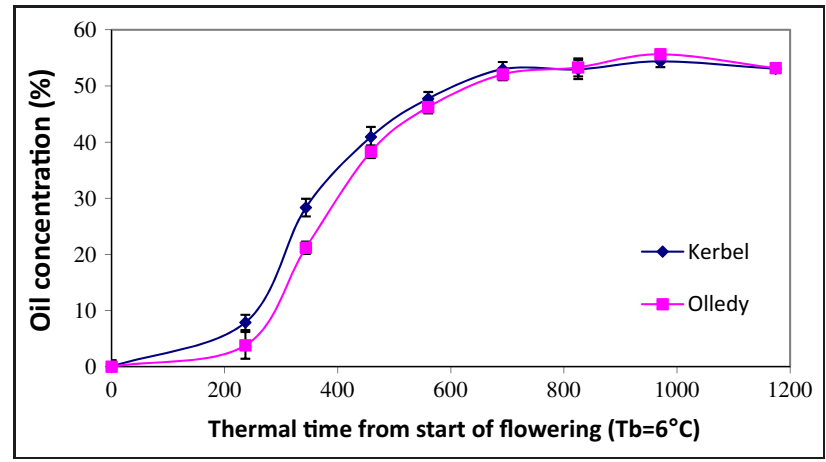

Fig. 3. Examples of oil concentration sigmoid pattern dynamics in two sunflower cultivars (Kerbel and Olledy) in Auzeville 2012 field experiment (from Andrianasolo, 2014). Error bars correspond to standard deviation.

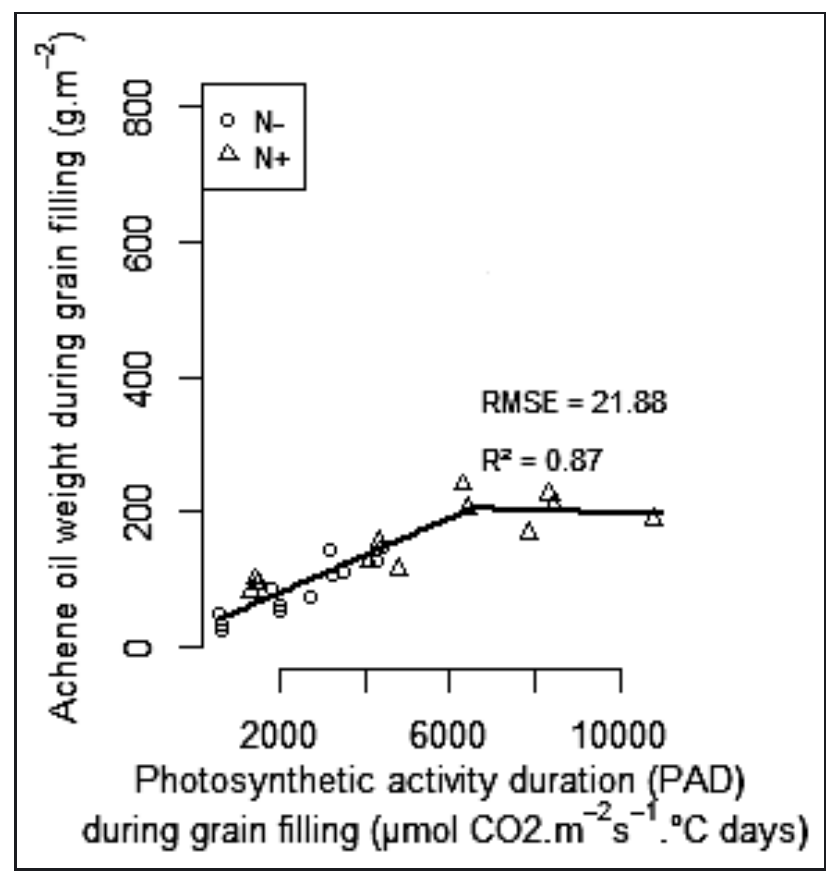

Fig. 4. Relationship between photosynthetic activity duration (PAD) and achene oil weight during grain filling in the cultivar Kerbel (2012 experiment, from Andrianasolo, 2014). PAD was computed from weekly photosynthetic activity measurements between mid-filling and end of grain filling, and integrated over time. Symbols were distinguished by nitrogen treatment (circle: limiting nitrogen situations; triangle: non-limiting nitrogen situations). Model was fitted with a bi-linear model; root mean squared error (RMSE) and coefficient of determination $\left(R^{2}\right)$ are indicated.

for space and/or nutrients (Alkio and Grimm, 2003; Merrien, 1992).

Oil quantity in the achene is mainly modulated by the ability of the leaves to maintain photosynthetic activity during grain filling (Fig. 4). For that reason, several studies related OC to the cumulative photosynthetically active radiation intercepted by the canopy during grain filling or to leaf area duration (LAD) as a proxy (Aguirrezabal et al., 2003; Dosio et al., 2000; Merrien, 1992; Picq and Abramovsky, 1989).

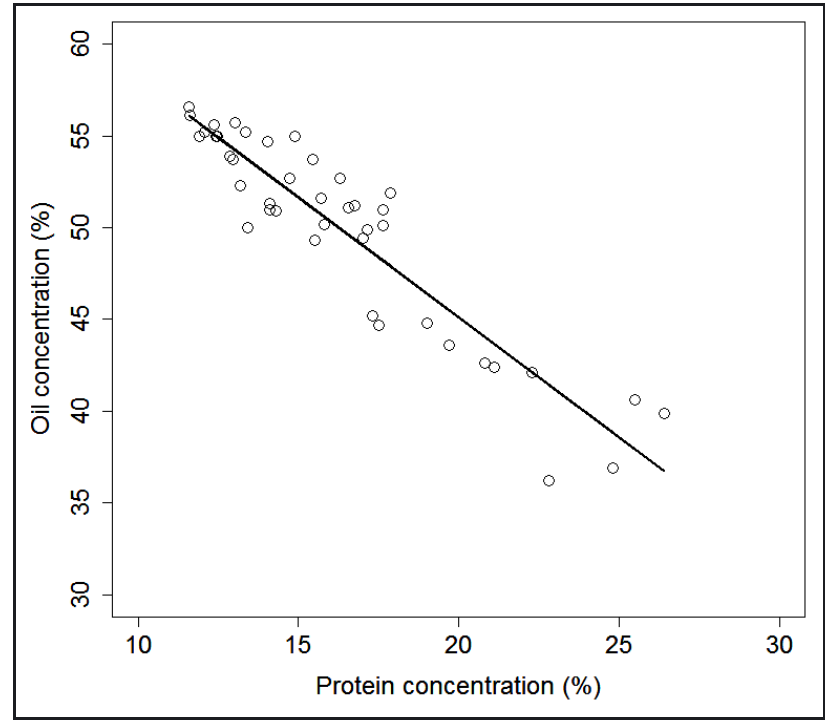

Fig. 5. Reverse relationship between oil and protein concentrations as observed in 2012 field experiment (Andrianasolo, 2014). 2 genotypes (Kerbel, Olledy), 2 nitrogen conditions ( $\mathrm{N}+$ : non-limiting; $\mathrm{N}$-: limiting), 2 plant densities (D1: 3 plants per $\mathrm{m}^{2}$; D2: 4.5 plants per $\mathrm{m}^{2}$ ) were combined in irrigated plots. Datapoints represent mean values of genotype $x$ nitrogen $x$ plant density treatments at harvest.

A supplemental part could be brought by pre-stored carbon in vegetative organs (Hall et al., 1989, 1990; Lopez-Pereira et al., 2008). The contribution of the latter could vary greatly depending on the genotype (Sadras et al., 1993), crop management (fertilization, Andrianasolo et al., 2014) and environmental conditions (water stress, Hall et al., 1989, 1990).

\subsection{Relationship between oil and protein concentrations}

It has been often established that in any cropping conditions, oil and protein concentrations are inversely related (Andrianasolo et al., 2014; Bauchot and Merrien, 1988; Diepenbrock et al., 2001; Roche, 2005) (Fig. 5). It interestingly appears that oil dynamics does not rely on protein since they do not accumulate at the same periods (proteins starting to accumulate before oil) and involve different metabolic pathways, although the precursor is similar: Acetyl-CoA. It is likely that the "shift" towards "more" lipogenesis or "more" proteogenesis is regulated by genotype and environmental factors (Bauchot and Merrien, 1988).

\section{Genotype, environment and crop management effects on oil concentration}

It is expected that a better understanding of oil concentration determinism - which influencing factors are most reported in the literature and how do they play on oil elaboration? - combined with improvements in the formalisms of existing crop models, should help to obtain more accurate predictions 
for oil concentration. Next sub-sections deal with the description of oil determining factors and their integration into crop models.

\subsection{Genotypic variation of OC}

Oil concentration (OC) is a character which has a strong genetic heritability but with some influence of environmental factors (Fick, 1978). The ratio between genotypic and phenotypic variances was estimated between 65 and $72 \%$ considering the entire achene (Fick, 1975; Shabana, 1974). The genetic control of OC in sunflower was also investigated through QTL analysis; several chromosomal regions associated with quantitative variation of oil content and other seed quality traits were identified by Ebrahimi et al. (2008). Balalic et al. (2012) analyzed the effects of 3 years, 3 hybrids and 8 sowing dates in Serbia. They concluded that $\mathrm{OC}$ was predominantly influenced by the hybrid (70\%) followed by the year (10\%) and sowing date $(7 \%)$, while the oil yield was predominantly influenced by the year (59\%), followed by the sowing date (13\%) and hybrid $(11 \%)$.

For in-depth analysis, oil concentration can be decomposed into four components:

$\mathrm{OC}(\%)_{\text {achene }}=\operatorname{Hull}(\%) * \mathrm{OC}_{\text {hull }}(\%)+\operatorname{Kernel}(\%) * \mathrm{OC}_{\text {kernel }}(\%)$.

Denis and Vear (1996) studied the relationships between individual achene weight, hull (\%) and OC (\%) among 40 RILs and 36 hybrids. They didn't conclude to systematic relationships between achene and hull weight nor achene weight and OC. Hull proportion is genetically determined (its broad sense heritability being from 27 to $32 \%$ according to Fick, 1978).

In Argentina, genetic improvement strongly contributed to increase OC in sunflower (Aguirrezabal et al., 2015): modern high-oil sunflower hybrids (47-53\% oil) have replaced low-oil varieties and hybrids (38-47\% oil). The increase in OC was due for $2 / 3$ to the increase of kernel (\%) (i.e. a decrease of the hull fraction) and for $1 / 3$ to an increase of $\mathrm{OC}_{\text {kernel }}$ (Connor and Hall, 1997; Lopez Pereira et al., 2000; Tang et al., 2006). OC increase would be related to the longer duration of active leaf area after flowering in more recent cultivars ("stay-green" character, De la Vega et al., 2011) rather than to a higher rate of oil accumulation (Izquierdo et al., 2008; Mantese et al., 2006).

However, Vear et al. (2003) who analyzed 30 years of breeding in the sunflower cultivars most grown in France did not conclude to a clear increase in OC contrastingly to grain yield improvement. However, when looking at the cultivars grown in France in 2014 and tested by Terres Inovia (40 oleic, 75 linoleic), it appears that $20 \%$ of oleic cultivars and $42 \%$ of linoleic cultivars had high (48-49\%) to very high OC (50$51 \%$ ) (Fig. 6). Only $11 \%$ of the cultivars had a low value of OC (44-45\%). Oil richness is a character which is explicitly considered for variety registration when calculating the final score which results in a wide offer of high-oil cultivars.

\subsection{Influence of temperature on OC}

In controlled conditions, Angeloni et al. (2012) identified a biphasic response to daily mean temperature, with no response up to $17-22{ }^{\circ} \mathrm{C}$ depending on the hybrid, and a steep

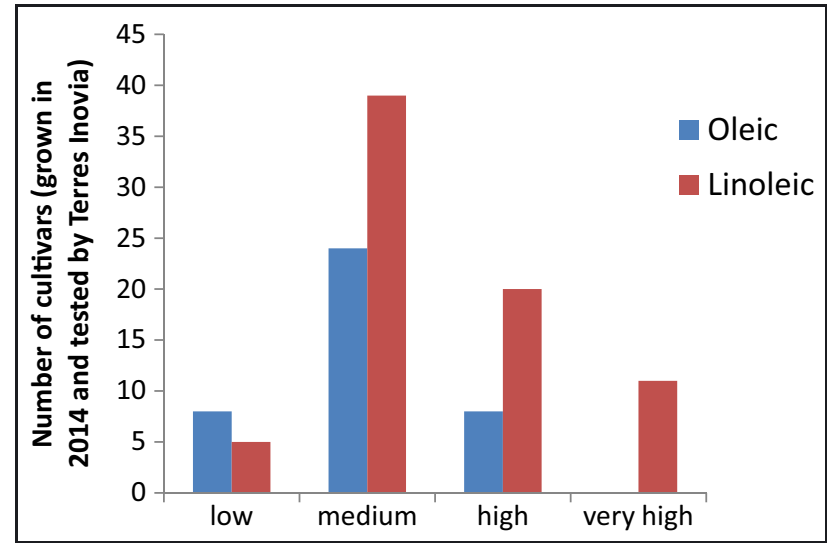

Fig. 6. Distribution of seed oil concentration among oleic (40) and linoleic (75) cultivars grown in 2014 and tested by Terres Inovia.

decrease at higher temperature. Canvin (1965) reported a reduction of $1.2 \%$ in oil content for each $1{ }^{\circ} \mathrm{C}$ rise. Chimenti et al. (2001) stated that very high temperatures $\left(>34^{\circ} \mathrm{C}\right)$ were responsible for a reduction of grain filling duration with negative impacts on kernel weight, oil accumulation and the increase of hull fraction. Rondanini et al. (2003) demonstrated that high temperatures $\left(>35^{\circ} \mathrm{C}\right)$ during flowering decreased OC through differential reductions of both kernel fraction and kernel oil concentration (with a higher decrease in kernel fraction), while high temperatures during grain filling affected kernel weight without affecting kernel oil percentage. Although most of this effect is related to the lower accumulation of carbon during the critical period due to the shortened grain-filling period under higher temperature, a direct effect of temperature on oil synthesis should be also considered (Aguirrezabal et al., 2015). This effect of temperature was related to maintenance respiration and photosynthesis processes which are similarly affected by high temperatures (Connor and Hall, 1997; Connor and Fereres, 1999).

However, controversial results have been reported about the effect of temperature on OC (Angeloni et al., 2012): while in field experiments a positive correlation between mean temperature and OC was observed (e.g. Nagao and Yamazaki, 1984; Unger and Thompson, 1982), the opposite effect was clearly evidenced in controlled or semi-controlled experiments (Canvin, 1965; Harris et al., 1978; Merrien, 1992). Field responses could be apparently attributed to temperature but due to environmental variables associated to heat (such as water stress). This disagreement among experimental reports also suggests a high level of complexity in the effect of temperature on sunflower yield and oil content as pointed by Hall et al. (2004).

Roche et al. (2006) suggested that changes in OC observed in field experiments with different sowing dates could be explained by differences in mean temperature during grain filling. Indeed numerous studies have considered the effects of various planting dates on $\mathrm{OC}$ and they generally concluded to a reduction of $\mathrm{OC}$ when delaying sowing date during springtime (e.g. Flagella et al., 2002; Goksoy et al., 1998; Petcu et al., 2010; Thompson and Heenan, 1994; Unger, 1980; Zheljazkov et al., 2009). De la Vega and Hall (2002) in Argentina reported 
a significant reduction in OC associated with a strong reduction in the duration of grain filling observed at late planting, and found that variation in grain OC between sowing dates was largely due to changes in kernel oil proportion, rather than to changes in kernel percentage.

However the effects attributed to high temperature (reduction of grain filling duration and carbon assimilation) could be also attributed to water stress as both environmental factors are often associated at field level. Aguirrezabal et al. (2015) also attributed the planting date effect to a reduction of intercepted radiation with late plantings.

\subsection{Influence of water availability on OC}

Often associated to rising temperatures, water stress generally increases with late sowing in spring and is partly responsible for lower OC with delayed planting as discussed above.

Numerous studies have been published on the effect of water stress on grain yield (Ebrahimi et al., 2008; Hall et al., 1989, 1990; Sadras et al., 1993), but less information is available on OC at least at achene level. When comparing four contrasted water regimes, Santonoceto et al. (2002) in Southern Italy clearly demonstrated the depressive effect of water constraint during the final stage of oil accumulation (plateau). For instance, Anastasi et al. (2010) and Alahdadi et al. (2011) observed $13 \%$ and $27 \%$ more oil with full irrigation than for rainfed sunflower in Southern Italy and Iran, respectively. Several other studies concluded to beneficial effects of supplemental irrigation on OC (e.g. Champolivier, Debaeke, Merrien, 2011; Sezen et al., 2011), the magnitude of the responses depending on natural water availability.

Water stress affects plant leaf area and decreases leaf photosynthesis mainly due to stomatal closure (Connor and Hall, 1997; Hsiao, 1973; Maury et al., 1996; Tardieu et al., 2014). Before flowering, leaf expansion is most affected; after flowering, a prolonged and severe water stress may result in premature senescence due to the increase of leaf temperature affecting the photochemical system (Cechin et al., 2006) and creating an oxidative stress (Maury et al., 2011).

Some adaptations have been reported. Hall et al. (1989, 1990) observed a stronger contribution of pre-flowering carbohydrates to achene filling in conditions of water stress. Blanchet et al. (1988) observed that assimilates were preferentially redirected towards the heads in conditions of severe water stress. This should be better evaluated on more contrasted ranges of genotypes.

\subsection{Influence of nitrogen status on OC}

It has been commonly observed that over- $\mathrm{N}$ fertilized situations (i.e. Nitrogen Nutrition Index $>1$ ) are responsible for lower OC and that slightly $\mathrm{N}$-deficient situations are generally optimal for maximizing OC (Connor et Hall, 1997; Diepenbrock et al., 2001; Geleta et al., 1997; Merrien, 1992; Ozer et al., 2004; Steer et al., 1986; Zheljazkov et al., 2009) (Fig. 7). This depressive effect could be explained by a dilution effect (Connor et Hall, 1997; Diepenbrock et al., 2001): in nonlimiting $\mathrm{N}$ conditions, all the achene components (hull, proteins, oil) are quantitatively higher (Andrianasolo, 2014) but

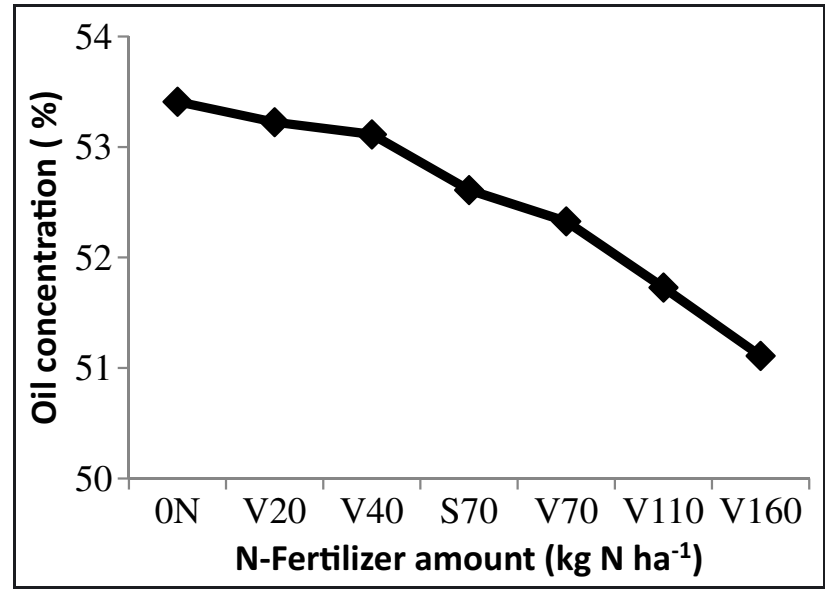

Fig. 7. Relationship between seed oil concentration (OC, \%) and Nfertilizer amount (kg N ha-1) applied at sowing (S) or during vegetative period (V). Field experiments conducted by Terres Inovia in South-Western France in 2010. Oil concentration at 9\% moisture and $2 \%$ impurities.

hull and protein weights increase more than oil weight which causes lower OC. $\mathrm{N}$ fertilization in sunflower must be finetuned to optimize grain yield and OC.

\subsection{Influence of plant density on OC}

Contradictory effects have been observed concerning the effect of plant density on OC in relation with environments and genotypes (Andrianasolo et al., 2012; Diepenbrock et al., 2001; Gubbels and Dedio, 1986; Rizzardi et al., 1992). The negative effect of increasing plant density on individual achene (and kernel) weight is well known; it has no systematic effect on OC. Increasing plant density reduces pericarp thickness (Lindström et al., 2006) which increases the kernel fraction and consequently OC. Uneven and low plant densities in farmer's fields were responsible for low OC observed at the cooperative level (Champolivier, Debaeke, Thibierge, 2011). Positive correlations between OC and plant density and between hull (\%) and plant density were observed in farmer's fields (Fig. 8).

\subsection{Influence of fungal diseases on OC}

Only fungal diseases which affect grain filling by stopping carbohydrates accumulation before physiological maturity are responsible for OC reduction; as they affect more oil accumulation in kernels than hull growth, drops in OC are expected in such diseased conditions. Main diseases affecting grain filling are phomopsis (Phomopsis/Diaporthe helianthi), phoma (Phoma macdonaldii/Leptosphaeria linquistii) and verticillium (Verticilllium dahliae) (Gulya et al., 1997).

Their development is favoured by high moisture within canopy between flower bud and the end of flowering, as a result of climatic conditions or crop management (high plant density, high $\mathrm{N}$ fertilizer rates, irrigation) (Debaeke et al., 2014).

Damages from Phomopsis stem canker comes from the disruption of water movements in stems caused by deep necrosis and vessel lesions. Late attacks are visible also on heads. 


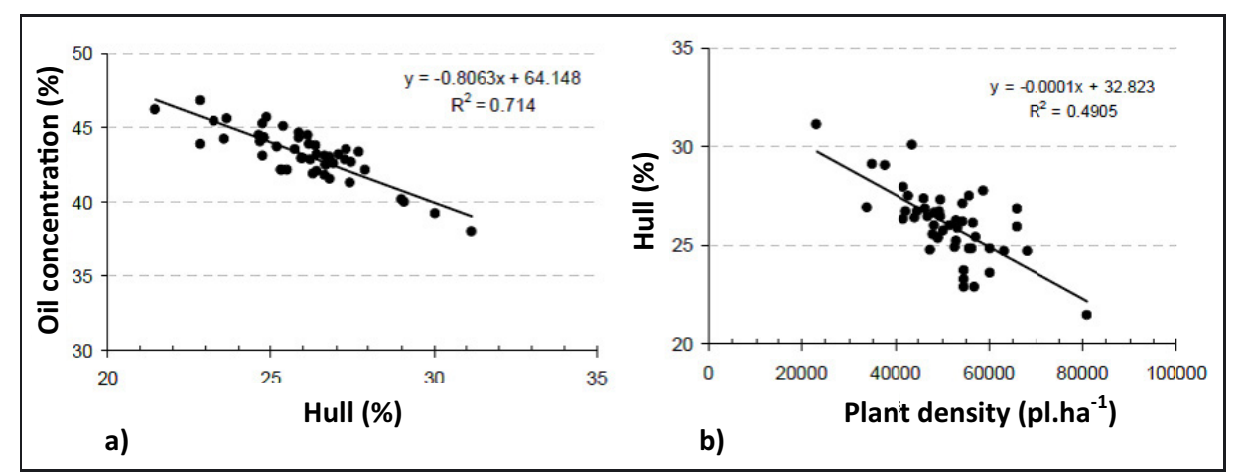

Fig. 8. Relationship between (a) oil and hull concentrations and (b) hull (\%) and plant density (plants ha-1) as evidenced in on-farm surveys in two production areas of South-Western France (Champolivier, Debaeke, Thibierge, 2011): cv. NK Countri, 2008. Oil concentration at 9\% moisture and $2 \%$ impurities.

For $10 \%$ of stems bearing girdling symptoms, 1 point of oil (and $0.2-0.3 \mathrm{t}$ of grain $\mathrm{ha}^{-1}$ ) could be lost (Terres Inovia, 2015). Diaz Franco and Ortegon Morales (1997) in Mexico observed losses up to 11 points of oil depending on the period of leaf infection.

OC losses from phoma attacks are probably lower. Two forms of the disease are frequently observed: simple stem attacks which are responsible of accelerated leaf senescence and probably reduced grain yield and oil content losses. However premature ripening due to phoma attacks at collar levels should affect grain filling more severely (Bordat et al., 2011). However the consequences on OC have not been assessed accurately so far in the absence of totally efficient fungicide protection.

Losses from Verticillium can be economically significant (Hoes, 1972; Zimmer and Zimmerman, 1972). Oil concentration of the kernels was reduced from 51.4 to $46.2 \%$, kernel density was reduced by about $10 \%$, and seeds of diseased plants were smaller.

Attacks of sclerotinia head rot (Sclerotinia sclerotiorum (Lib.) de Bary) are responsible for OC reduction; Gulya et al. (1989) observed slight but significant reductions (up to 1 percentage point of oil).

Tolerant varieties are available for those diseases (phomopsis and verticillium) and agronomic practices can be used for escaping, avoiding and attenuating disease incidence and severity (Debaeke et al., 2014).

\subsection{Conceptual model of oil elaboration and determining factors}

The following conceptual and simple model was proposed to summarize the previous information about sunflower oil response to main determining physiological and agronomical factors (Fig. 9). Only genotype and abiotic factors (plant density, temperature, water and nitrogen) were represented in a first approach. We bring to your attention that knowledge on OC elaboration and determinism was not always that integrative (that is, studies focused on determining factors, but separately). Therefore, the integration of that information was made progressively in crop models, from very empirical tools to more process-based oriented ones.

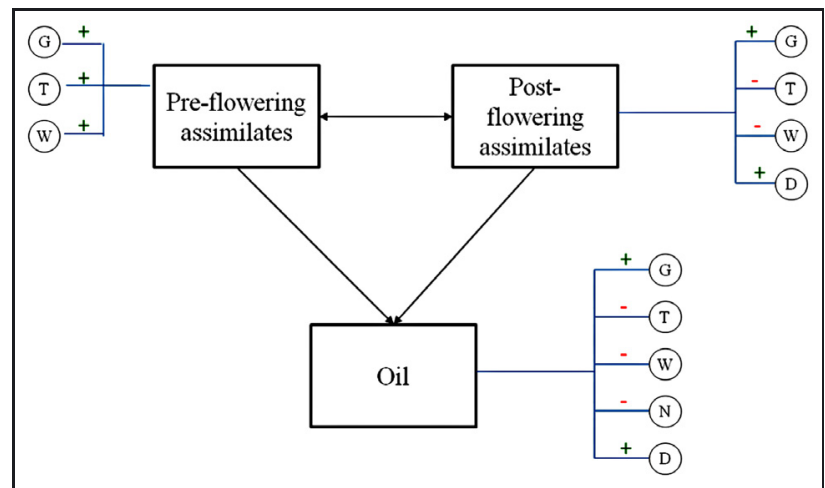

Fig. 9. Conceptual model of oil determinism in sunflower grains. Reliance on pre- and post-flowering assimilates is indicated. Doublehead arrows between both reflects the idea that pre-assimilates are mobilized only when post-flowering assimilates are lacking. Genotype and abiotic factors effects (genotype (G), stress temperature (T), water stress (W), nitrogen (N) and plant density (D)) are represented in blue lines; positive (triggering the component) and negative effects (reducing or blocking the component) are indicated by green cross and red line respectively. It is assumed that plant density effect is globally positive.

\section{Crop models for predicting oil concentration}

\subsection{Generic models and models developed for oilseed crops}

In some generic crop models, rather simple modeling approaches were included to simulate roughly oil accumulation and final OC for oilseed crops (sunflower, oilseed rape, soybean, cotton). In STICS model (Brisson et al., 2003), a daily accumulation of lipids in the grain is computed with a constant rate up to physiological maturity. In CROPGRO, parameterized for peanut, cotton and soybean, OC is considered to be proportional to grain yield (Boote et al., 2003). In CERES-rape (Gabrielle et al., 1998), OC is deduced from the computation of $\mathrm{N}$ concentration of pods and pods weights. In Azodyn-Colza model (Jeuffroy et al., 2006), OC at harvest is estimated by a statistical relationship with grain protein concentration and individual grain weight. Li et al. (2009) developed a dynamic 
cotton model where oil accumulation depends on the ability of each boll to synthesize fatty acids and on daily demand in oil (daily weight of boll multiplied by maximal oil concentration, both modulated by temperature and nitrogen factors).

\subsection{Dynamic crop models developed specifically for sunflower}

QSUN was developed for simulating yield, growth and oil content of sunflower in dry conditions of Australia (Chapman et al., 1993). OC is simulated in a linear pattern starting from flowering and ending 25 days after flowering with a maximal OC set at $45 \%$. Similarly, in OILCROP-SUN (Villalobos et al., 1996), OC is simulated through a steady rate established at 13 days after the onset of flowering. In Pereyra-Irujo and Aguirrezabal (2007) model, OC is a function of cumulative radiation intercepted by the canopy between 250 and $450{ }^{\circ} \mathrm{C}$ days after flowering (Aguirrezabal et al., 2003) and plant density with a limitation by maximum attainable OC (50\%). In SUNFLO model (Casadebaig, 2008, 2011; Debaeke et al., 2010), OC is estimated through a multivariable linear regression model that include descriptors of leaf canopy functioning, abiotic stress indices and genotypic information.

\subsection{Improvements brought by integrating more physiological knowledge in oil deposition simulation}

From the previous review of models predicting OC for oilseeds crops, we came to the following conclusions:

(i) most existing models proposed very empirical formalisms for simulating $\mathrm{OC}$ at harvest (generally fixed rates; OC determined by protein concentration; OC modulated by grain filling duration and temperature; no effects of $\mathrm{N}$ and water stress);

(ii) the oil modules were seldom evaluated and no predictive quality was given;

(iii) when oil modules were evaluated, they only considered non-limiting conditions and a narrow range of genotypes, which limits the extensibility of the models. In the absence of simulated stress effect, OC was generally overestimated.

Therefore, Andrianasolo (2014) and Andrianasolo et al. (2014) assumed that OC prediction could be valuably improved by integrating more physiological processes in both statistical and dynamic models.

\subsubsection{A statistical approach to predict oil concentration}

The linear OC model from SUNFLO (Casadebaig et al., 2011) was kept as a starting point for further improvement. Andrianasolo et al. (2014) assumed that the use of a larger potential list of explanatory variables, applied to a larger database from contrasted experimental treatments should reduce the prediction error of the SUNFLO model.
A dataset was built from experiments conducted between 2000 and 2011 by Terres Inovia and INRA, involving a total of 18 locations and 61 sunflower varieties. Different types of agronomic trials were carried out, such as those implying variations of nitrogen rates (from 0 to $160 \mathrm{~kg} \mathrm{~N} \mathrm{ha}^{-1}$ ), plant densities (from 3 to 8 plants $\mathrm{m}^{-2}$ ), irrigation (from 0 to $200 \mathrm{~mm}$ ), varieties (from 8 to 20 varieties per site), and those in which $\mathrm{N}$ rates and irrigation amounts or plant densities and $\mathrm{N}$ rates were combined. The whole dataset consisted of 418 USMs (Units of SiMulation), each USM corresponding to the combination of a variety, a treatment (management), an experimental site (soil) and a growing season (climate).

On the other hand, a set of 25 putative explanatory variables was proposed following an extensive study of literature. Those potential predictors were indicators of crop growth and senescence (leaf area duration, radiation interception, radiation use efficiency, ...), nitrogen and water stress indicators (Nitrogen Nutrition Index, nitrogen uptake, normalized evapotranspiration, fraction of transpirable soil water, ...), crop management (plant density) and varietal information (potential OC).The originality of the study relies on the calculation of these predictors on different growth periods: pre-flowering, post-flowering or oil deposition period $\left(250\right.$ to $450{ }^{\circ} \mathrm{C}$ days after flowering, Aguirrezabal et al., 2003).

Andrianasolo et al. (2014) developed three types of statistical models: multiple linear regression (MLR, Fig. 10), generalized additive model (GAM) and regression tree (RT) and compared them to the most complete model for sunflower developed by Pereyra-Irujo and Aguirrezabal (2007) in Argentina. Authors proceeded to model simplification by the use of Bayesian methods, following the assumption of parsimony. The three newly built models displayed up to 10 predictors, while the Pereyra-Irujo and Aguirrezabal (2007) model was composed of 3 predictors. Evaluation was performed by cross-validation. Errors ranged from 1.90 (GAM model) to 2.54 (regression tree), while the Argentinian model performed poorly in French conditions (RMSEP $=3.3$ oil points) and was not able to reproduce plant density and $\mathrm{N}$ fertilization effects on OC. New statistical models were able to simulate the hierarchy of varieties in their potential OC since the latter accounted for more than $50 \%$ of final oil concentration variability, while solar radiation was the most determinant factor in the Pereyra-Irujo and Aguirrezabal (2007) model.

\subsubsection{Proposal of a dynamic modeling approach}

The potential interest of a dynamic crop model is that it is expected to provide reliable predictions of OC soon before harvest as well as helping to understand at which time oil dynamics was affected by environmental stress or management.

Andrianasolo (2014) proposed a "source-sink" based dynamic model describing on a daily step nitrogen and carbon assimilations and remobilizations during grain filling. Priority rules were established for carbon and nitrogen depletion from "source" organs, as well as for their allocation into "sink" organs. Photosynthesis using the approach of Monteith and Moss (1977) (radiation use efficiency) and nitrogen uptake processes (from Pan et al., 2006) were taken into account. Water and nitrogen stresses were computed. Inputs were climatic data, soil 


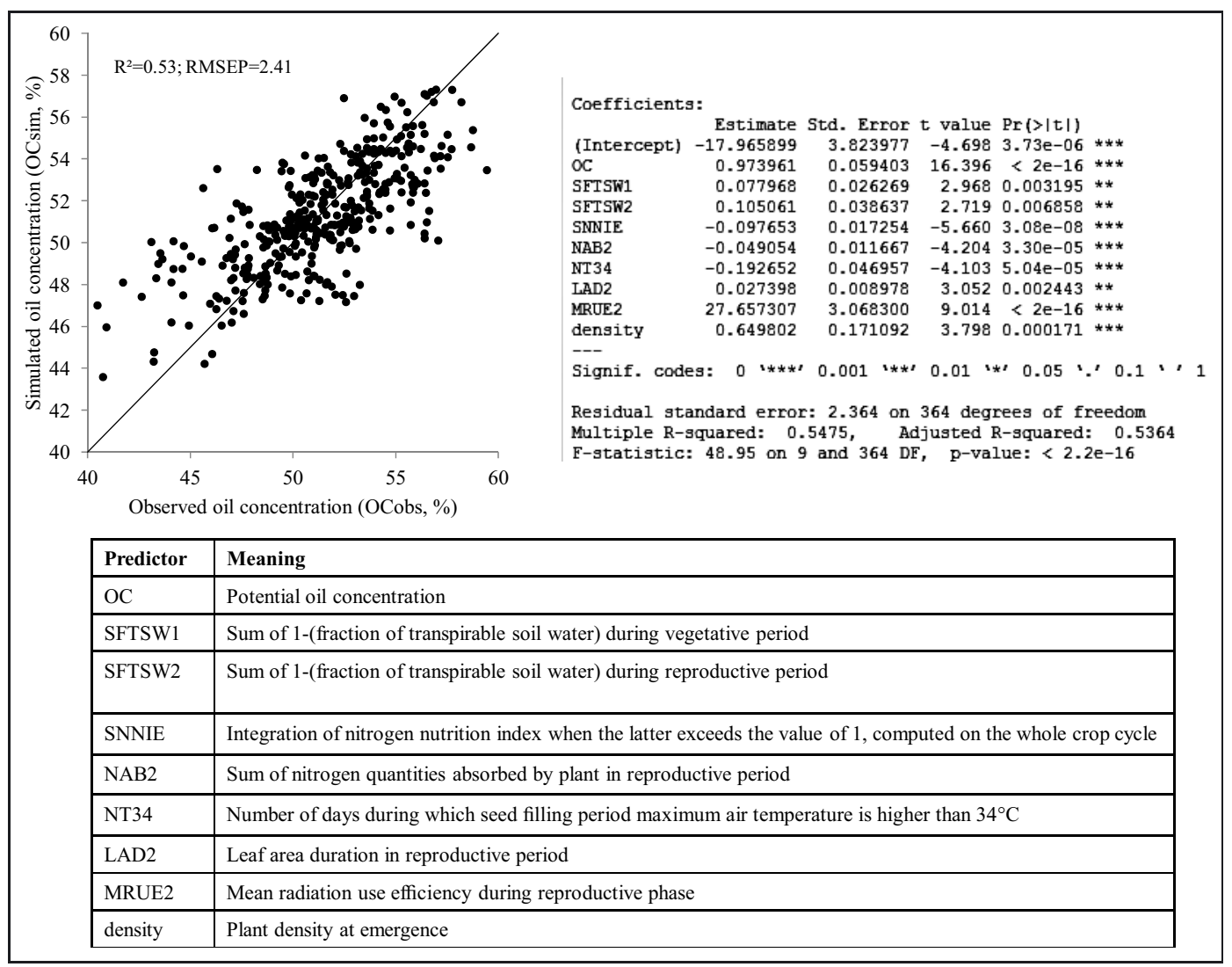

Fig. 10. Statistical prediction of OC with a multiple linear regression (MLR) model (Andrianasolo et al., 2014). Goodness-of-fit (relative mean squared error of prediction RMSEP and model efficiency EF) and meanings and values of the 9 predictors are given.

nitrogen and water availability (simulated by SUNFLO crop model) and initial states of "source" and "sink" organs at flowering and main outputs were oil and protein concentrations and weights per $\mathrm{m}^{2}$. The model was calibrated on 24 USMs in 2012 while evaluation was carried out on 50 USMs (trials conducted by Terres Inovia and INRA in 2012 and 2013). Global trends were well reproduced for all "source" and "sink" components (Fig. 11) but most variables tended to be overestimated. The main indicators of model quality for predicting OC were: $\mathrm{RMSE}=6.1(\%)$, efficiency $=0.97, R^{2}=0.94$ and Bias $=-0.06(\%)$. Following a sensitivity analysis, we suggested that the reduction of the number of the parameters, as well as a better description of photosynthesis and nitrogen uptake processes and a better parameterization of genotype and nitrogen effects, should help reduce prediction error and provide a relevant tool for predicting OC in other oilseed crops.

\section{Conclusions and perspectives}

This paper provided an integrative view of the most determining factors of oil concentration in sunflower and the way to predict $\mathrm{OC}$ as a function of genotype, environment and management. Such a review was motivated by the fact that many studies were carried out separately for analyzing either genotype or crop management effects, but they were seldom put in relation or compared. Besides, the review of existing crop

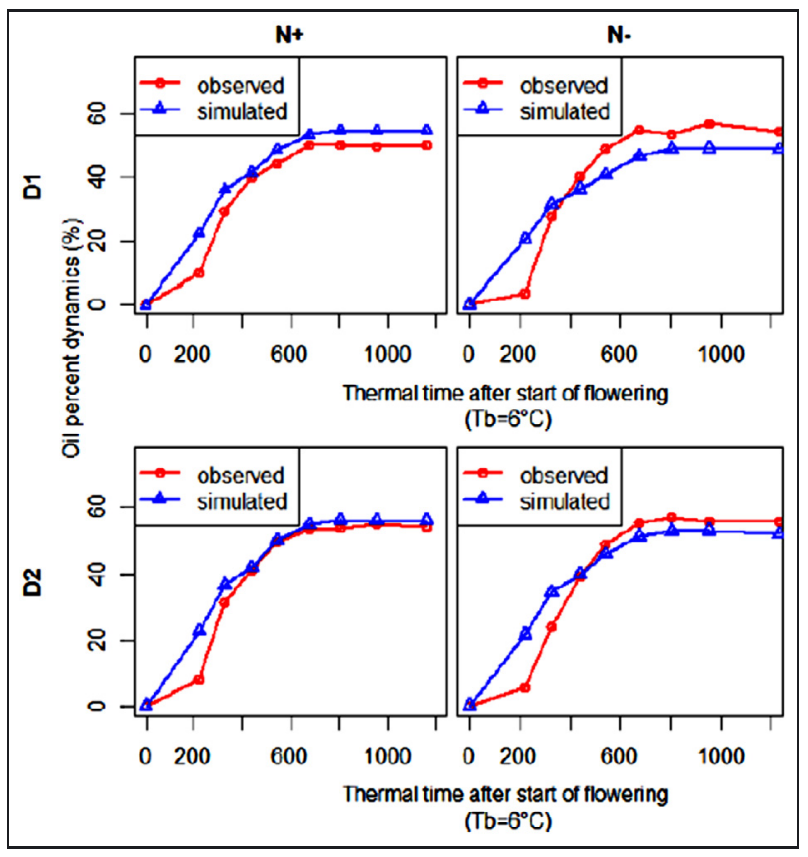

Fig. 11. Dynamics of oil concentration as simulated by a dynamic crop model (from Andrianasolo, 2014). Situations correspond to mean patterns of Kerbel and Olledy cultivars under contrasted nitrogen treatments ( $\mathrm{N}+$ : non-limiting, $150 \mathrm{~kg} \mathrm{~N} \mathrm{ha}^{-1} ; \mathrm{N}-$ : no fertilization) and plant densities (D1: 3 plants $\mathrm{m}^{-2}$; D2: 4.5 plants $\mathrm{m}^{-2}$ ) in 2012 field experiment (INRA Auzeville). 
models led to the conclusion that they were all most empirical and not evaluated for OC prediction. It was assumed that a better understanding of oil physiology, combined with improvements in crop modeling should permit to improve achene OC prediction which determines the industrial yield of the grains. Most recent works were dedicated to the integration of process-based indicators into statistical and dynamic models of OC (Andrianasolo, 2014). Statistical models proved to perform better while dynamic models still deserved in-depth studies of post-flowering photosynthesis and nitrogen uptake in sunflower, as well as more accurate description of genotypic variability.

Acknowledgements. This work was supported by the Association Nationale de la Recherche et de la Technologie and Terres Inovia (CIFRE No. 2010/1467). We greatly thank the contribution of the analytical laboratory from Terres Inovia in Ardon (resp. A. Merrien).

\section{References}

Agreste. 2015. La statistique, l'évaluation et la prospective agricole [WWW Document], Available at: agreste.agriculture.gouv. $\mathrm{fr} /$ (accessed 10.2015).

Aguirrezabal LAN, Lavaud Y, Dosio GA, Izquierdo NG, Andrade FH, Gonzalez LM. 2003. Intercepted solar radiation during seed filling determines sunflower weight per seed and oil concentration. Crop Sci 43: 152-161.

Aguirrezabal LAN, Martre P, Pereyra-Irujo G, Echarte MM, Izquierdo N. 2015. Improving grain quality: ecophysiological and modeling tools to develop management and breeding strategies. In: Sadras VO, Calderini D. (eds.), Crop Physiology: Applications for genetic improvement and agronomy. Elsevier, pp. 423-465.

Alkio M, Grimm E. 2003. Vascular connections between the receptacle and empty achenes in sunflower (Helianthus annuus L). $J$. Exp. Bot. 54: 345-348.

Alahdadi I, Oraki H, Parhizkar Khajani F. 2011. Effect of water stress on yield and yield components of sunflower hybrids. Afr. J. Biotechnol. 10: 6504-6509.

Anastasi U, Santonoceto C, Giuffre AM, Sortino O, Gresta F, Abbate V. 2010. Yield performance and grain lipid composition of standard and oleic sunflower as affected by water supply. Field Crops Res. 119: 145-153.

Andrianasolo FN. 2014. Modélisation statistique et dynamique de la composition de la graine de tournesol (Helianthus annuus L.) sous l'influence des facteurs agronomiques et environnementaux, Ph.D. thesis, INP Toulouse.

Andrianasolo FN, Champolivier L, Maury P, Debaeke P. 2012. Plant density contribution to seed oil content: the responses of contrasting sunflower genotypes grown in multi-environmental network. In: Proc. 18th Int. Sunf. Conf., Mar del Plata, Argentina, pp. 724 729.

Andrianasolo FN, Casadebaig P, Maza E, Champolivier L, Maury P, Debaeke P. 2014. Prediction of sunflower grain oil concentration as a function of variety, crop management and environment using statistical models. Eur. J. Agron. 54: 84-96.

Angeloni P, Echarte MM, Aguirrezabal LAN. 2012. Temperature during grain filling affects grain weight and oil concentration in sunflower hybrid both directly and through the reduction of radiation interception. In: Proc. 18th Int. Sunf. Conf., Mar del Plata, Argentina, pp. 354-359.
Balalic I, Zoric M, Brankovic G, Terzic S, Crnobarac J. 2012. Interpretation of hybrid $\times$ sowing date interaction for oil content and oil yield in sunflower. Field Crops Res. 137: 70-77.

Bauchot A, Merrien A. 1988. Teneur en protéines des graines de tournesol et état protéique foliaire: revue bibliographique. Inf. Tech. CETIOM 102: 18-28.

Berger M, Ayerdi-Gotor A, Sarrafi A, Maury P, Daydé J, Calmon A. 2010. Compréhension du determinisme de la qualité des huiles du tournesol face aux nouvelles attentes OCL 17: 171-184.

Blanchet R, Piquemal M, Cavalié G, Hernandez M, Quinones H. 1988. Influence de contraintes hydriques sur la répartition des assimilats entre les organes du tournesol. In: Proc. 12th Int. Sunf. Conf., Novi-Sad, Yugoslavia, pp. 124-129.

Boote KJ, Jones JW, Batchelor WD, Nafziger ED, Myers O. 2003. Genetic coefficients in the CROPGRO-Soybean model. Agron. J. 95: 32-51.

Bordat A, Debaeke P, Dechamp-Guillaume G, Mestries E, Seassau C, Vincourt P. 2011. Phoma et dessèchement précoce du tournesol. Coll Les Points Techniques du CETIOM, 86 p.

Borredon ME, Berger M, Dauguet S, et al. 2011. Débouchés actuels et futures du tournesol produit en France - Critères de qualité. Innov. Agron. 14: 19-38.

Brisson N, Gary C, Justes E, et al. 2003. An overview of the crop model STICS. Eur. J. Agron. 18: 309-332.

Cancalon P. 1971. Chemical composition of sunflower seed hulls. $J$. Am. Oil Chem. Soc. 48: 639-631.

Canvin DT. 1965. The effect of temperature on the oil content and fatty acid composition of the oil from several oil seed crops. Can. J. Bot. 43: 63-69.

Casadebaig P. 2008. Analyse et modélisation de l'interaction génotype-environnement-conduite de culture: application au tournesol (Helianthus annuus L), Ph.D. thesis, INP Toulouse.

Casadebaig P, Guilioni L, Lecoeur J, Christophe A, Champolivier L, Debaeke P. 2011. SUNFLO, a model to simulate genotypespecific performance of the sunflower crop in contrasting environments. Agric. For. Met. 151: 163-178.

Cechin I, Rossi SC, Oliveira VC, Fumis TF. 2006. Photosynthetic responses and proline content of mature and young leaves of sunflower plants under water deficit. Photosynthetica 44: 143-146.

Champolivier L, Merrien A. 1996. Évolution de la teneur en huile et de sa composition en acides gras chez deux variétés de tournesol (oléique ou non) sous l'effet de températures différentes pendant la maturation des graines. OCL 3: 140-144.

Champolivier L, Kichey S, Reau R, Le Bail M. 2004. An analysis of the economical effects of crop management modifications in order to improve the sunflower oilseed content at the scale of a primary elevator supplying area. In: Proc. 16th Int. Sunf. Conf., Fargo, ND, USA, pp. 207-212.

Champolivier L, Debaeke P, Thibierge J, et al. 2011. Construire des stratégies de production adaptées aux débouchés à l'échelle du bassin de collecte. Innov. Agron. 14: 39-57.

Champolivier L, Debaeke P, Merrien A. 2011. Pourquoi irriguer le tournesol, une culture réputée tolérante à la sécheresse? Innov. Agron. 14: 151-164.

Chapman SC, Hammer GL, Meinke H. 1993. A sunflower simulation model: I. Model development. Agron. J. 85: 725-735.

Chervet B, Vear F. 1989. Evolution des caractéristiques de la graine et du capitule chez le tournesol au cours de la maturation. Agronomie 9: 305-313.

Chimenti CA, Hall AJ, Lopez MS. 2001. Embryo-growth rate and duration in sunflower as affected by temperature. Field Crops Res. 69: 81-88. 
Connor DJ, Fereres E, 1999. A dynamic model of crop growth and partitioning of biomass. Field Crops Res. 63, 139-157.

Connor DJ, Hall AJ. 1997. Sunflower physiology. In Schneiter AA (ed.), Sunflower Technology and Production, Agronomy Monograph 35, ASA-CSSA-SSSA. Madison, WI, USA, pp. 113 182.

De la Vega AJ, Hall AJ. 2002. Effects of planting date, genotype and their interaction on sunflower yield. II. Components of oil yield. Crop Sci. 42: 1202-1210.

De la Vega AJ, Cantore MA, Sposaro MM, Trapani N, Lopez Pereira M, Hall AJ. 2011. Canopy stay-green and yield in non-stressed sunflower. Field Crops Res. 121: 175-185.

Debaeke P, Casadebaig P, Haquin B, Mestries E, Palleau JP, Salvi F. 2010. Simulation de la réponse variétale du tournesol à l'environnement à l'aide du modèle SUNFLO. OCL 17: 143-151.

Debaeke P, Mestries E, Desanlis M, Seassau C. 2014. Effects of crop management on the incidence and severity of fungal diseases in sunflower In: Arribas JE (ed.), Sunflowers: Growth and Development, Environmental Influences and Pests/Diseases. Nova Science Pubs, New York, USA, pp. 201-226.

Denis L, Vear F. 1996. Variation of hullability and other seed characteristics among sunflower lines and hybrids. Euphytica 87: 177187.

Diaz Franco A, Ortegon Morales, A. 1997. Influence of sunflower stem canker (Diaporthe helianthi) on seed quality and yield during seed development. Helia 20: 57-62.

Diepenbrock W, Long M, Feil B. 2001. Yield and quality of sunflower as affected by row orientation, row spacing and plant density. Bodenkultur 52: 29-36.

Dosio GAA, Aguirrezabal LAN, Andrade FH, Pereyra VR. 2000. Solar radiation intercepted during seed filling and oil production in two sunflower hybrids. Crop Sci. 40: 1637-1644.

Ebrahimi A, Maury P, Berger M, et al. 2008. QTL mapping of seedquality traits in sunflower recombinant inbred lines under different water regimes. Genome 51: 599-615.

Echarte MM, Pereyra-Irujo PI, Covi M, Izquierdo NG, Aguirrezabal LAN. 2010. Producing better sunflower oils in a changing environment, in: Advances in Fats and Oil Research, Transworld Research Network Mabel Cristina Tomás, Argentina, pp. 1-23

FAO. 2014. Food and Agriculture Organization of the United Nations, [WWW Document], Available at: http://www.fao.org/ (accessed 08/2014).

Fick GN. 1975. Heritability of oil content in sunflowers. Crop Sci. 15: 77-78.

Fick GN. 1978. Sunflower breeding and genetics. In: JF Carter (ed.), Sunflower Science and Technology. Agronomy Monograph 19, ASA-CSSA-SSSA. Madison, WI, USA, pp. 279-337.

Flagella Z, Rotunno T, Tarantino E, Di Caterina R, De Caro A. 2002. Changes in seed yield and oil fatty acid composition of high oleic sunflower (Helianthus annuus $\mathrm{L}$ ) hybrids in relation to the sowing date and the water regime. Eur. J. Agron. 17: 221-230.

Gabrielle B, Denoroy P, Gosse G, Justes E, Andersen MN. 1998. Development and evaluation of a CERES-type model for winter oilseed rape. Field Crops Res. 57: 95-111.

Geleta S, Baltensperger DD, Binford GD, Miller JF. 1997. Sunflower response to nitrogen and phosphorus in wheat-fallow cropping systems. J. Prod. Agric. 10: 466-472.

Goffner D, Cazalis R, du Sert CP, Calmes J, Cavalié G. 1988. 14C photoassimilate partitioning in developing sunflower seeds. $J$. Exp. Bot. 39: 1411-1420.

Goksoy AT, Turan ZM, Acikgoz E. 1998. Effect of planting date and plant population on seed and oil yields and plant characteristics in sunflower (Helianthus annuus L). Helia 21 (28): 107-115.
Gubbels GH, Dedio W. 1986. Effect of plant density and soil fertility on oilseed sunflower genotypes. Can. J. Plant Sci. 66: 521-527.

Gulya TJ, Vick BA, Nelson BD. 1989. Sclerotinia Head Rot of sunflower In North-Dakota - 1986 incidence, effect on yield and oil components, and sources of resistance. Plant Dis. 73: 504-507.

Gulya TJ, Rashid KY, Masirevic SM. 1997. Sunflower diseases In: Schneiter AA (ed.), Sunflower Technology and Production, ASACSSA-SSSA. Madison, WI, USA, pp. 263-379.

Hall AJ. 2004. Advances in the physiology of the sunflower crop: a ten-year progress report. In: Proc.16th Int. Sunf. Conf., Fargo, North Dakota, USA, pp. 29-41.

Hall AJ, Connor DJ, Whitfield DM. 1989. Contribution of preanthesis assimilates to grain-filling in irrigated and water-stressed sunflower crops. I. Estimates using labelled carbon. Field Crops Res. 20: 95-112.

Hall AJ, Whitfield DM, Connor DJ. 1990. Contribution of preanthesis assimilates to grain-filling in irrigated and water-stressed sunflower crops. II. Estimates from a carbon budget. Field Crops Res. 24: 273-294.

Harris HC, McWilliams JR, Mason WK. 1978. Influence of temperature on oil content and composition of sunflower seed. Aust. J. Agric. Res. 29: 1203-1212.

Hoes A. 1972. Losses due to Verticillium wilt in sunflower. Phytopathol. 62: 764.

Hsiao TC. 1973. Plant responses to water stress. Ann. Rev. Plant Physiol. 24: 519-570.

Izquierdo NG, Dosio GAA, Cantarero M, Lujan J, Aguirrezabal LAN. 2008. Weight per grain, oil concentration, and solar radiation intercepted during grain filling in black hull and striped hull sunflower hybrids. Crop Sci. 48: 688-699.

Jeuffroy MH, Valantin-Morison M, Champolivier L, Reau R. 2006. Azote, rendement et qualité des graines: mise au point et utilisation du modèle Azodyn-colza pour améliorer les performances du colza vis-à-vis de l'azote. OCL 13: 388-392.

Jouffret P, Labalette F, Thibierge J. 2011. Atouts et besoins en innovations du tournesol pour une agriculture durable. Innov. Agron. 14: $1-17$.

Knowles PF. 1978. Morphology and anatomy. In: Carter JF. (ed.), Sunflower Science and Technology. Agronomy Monograph 19, ASA-CSSA-SSSA. Madison. WI, USA, pp. 55-87.

Li W, Zhou Z, Meng Y, Xu N, Fok M. 2009. Modeling boll maturation period, seed growth, protein, and oil content of cotton (Gossypium hirsutum L.) in China. Field Crops Res. 112: 131140.

Lindström LI, Pellegrini CN, Aguirrezabal LAN, Hernández LF. 2006. Growth and development of sunflower fruits under shade during pre and early post-anthesis period. Field Crops Res. 96: 151-159.

Lindström LI, Pellegrini CN, Hernandez LF. 2007. Histological development of the sunflower fruit pericarp as affected by pre-and early post-anthesis canopy shading. Field Crops Res. 103: 229238.

Lopez Pereira M, Trapani N, Sadras VO. 2000. Genetic improvement of sunflower in Argentina between 1930 and 1995: Part III. Dry matter partitioning and grain composition. Field Crops Res. 67: 215-221.

Lopez Pereira M, Berney A, Hall AJ, Trapani N. 2008. Contribution of pre-anthesis photoassimilates to grain yield: Its relationship with yield in Argentine sunflower cultivars released between 1930 and 1995. Field Crops Res. 105: 88-96.

Mantese AI, Medan D, Hall AJ. 2006. Achene structure, development and lipid accumulation in sunflower cultivars differing in oil content at maturity. Ann. Bot. 97: 999-1010. 
Maury P, Mojayad F, Berger M, Planchon C. 1996. Photosynthesis response to drought acclimation in two sunflower genotypes. Physiol. Plant 98: 57- 66.

Maury P, Langlade N, Grieu P, et al. 2011. Ecophysiologie et génétique de la tolérance à la sécheresse chez le tournesol. Innov. Agron. 14: 123-138.

Merrien A. 1992. Physiologie du tournesol. CETIOM, Paris, 65 p.

Merrien A, Krouti M, Diaz J. 2010. Usage du proche infrarouge pour la détermination de la qualité des graines oléagineuses. OCL 17: 71-74.

Monteith JL, Moss CJ. 1977. Climate and the efficiency of crop production in Britain. Philos. Trans. Royal Soc. Lond. B Biol. Sci. 281: 277-294.

Nagao A, Yamazaki M. 1984. Effect of temperature during maturation on fatty acid composition of sunflower seed. Agric. Biol. Chem. 48: 553-555.

Ozer H, Polat T, Ozturk E. 2004. Response of irrigated sunflower (Helianthus annuиs L.) hybrids to nitrogen fertilization: growth, yield and yield components. Plant Soil Environ. 50: 205-211.

Pan J, Zhu Y, Jiang D, Dai T, Li Y, Cao W. 2006. Modeling plant nitrogen uptake and grain nitrogen accumulation in wheat. Field Crops Res. 97: 322-336.

Pereyra-Irujo GA, Aguirrezábal LAN. 2007. Sunflower yield and oil quality interactions and variability: Analysis through a simple simulation model. Agric. For. Met. 143: 252-265.

Petcu E, Babeanu N, Popa O, Partal E, Pricop SM. 2010. Effect of planting date, plant population and genotype on oil content and fatty acid composition in sunflower. Roman. Agric. Res. 27: $53-57$.

Picq G, Abramovsky, P. 1989. Indicateurs et conditions de croissance associés à la teneur et au rendement en huile et en protéines des akènes de tournesol (Helianthus annuus). Inf. Tech. CETIOM 108: 18-29.

Pilorgé E. 2010. Nouveau contexte environnemental et réglementaire: quel impact pour la culture du tournesol? OCL 17: 136-138.

Piva G, Bouniols A, Mondies G. 2000. Effect of cultural conditions on yield, oil content and fatty acid composition of sunflower kernel. In: Proc. 15th Int. Sunf. Conf., Toulouse, France, pp. 61-66.

Prolea, 2009. La filière française des huiles et protéines végétales [WWW Document], Available at: http://www.prolea.com/ (accessed 10/2015).

Prolea, 2012. De la production à la consommation. Statistiques des Oléagineux et Protéagineux. Prolea Documentation, Paris, 48 p.

Quere L. 2004. Des facteurs clés limitants pour le tournesol identifiés en 2003. Oléoscope 79: 31-32.

Rizzardi MA, da Silva PRF, da Rocha AB. 1992. Dry matter and oil partitioning in sunflower achenes as a function of cultivar and plant density. In Proc. 13th Int. Sunf. Conf., Pisa, Italy, pp. 7-11.

Roche J. 2005. Composition de la graine de tournesol (Helianthus annuus L.) sous l'effet conjugué des contraintes agrienvironnementales et des potentiels varietaux, Ph.D. thesis, INP Toulouse.

Roche J, Bouniols A, Mouloungui Z, Barranco T, Cerny M. 2006. Management of environmental crop conditions to produce useful sunflower oil components. Eur. J. Lipid Sci. Technol. 108: 287-297.
Rondanini D, Savin R, Hall AJ. 2003. Dynamics of fruit growth and oil quality of sunflower (Helianthus annuus L.) exposed to brief intervals of high temperature during grain filling. Field Crops Res. 83: 79-90.

Sadras VO, Connor DJ, Whitfield DM. 1993. Yield, yield components and source-sink relationships in water-stressed sunflower. Field Crops Res. 31: 27-39.

Santonoceto C, Anastasi U, Riggi E, Abbate V. 2003. Accumulation dynamics of dry matter, oil and major fatty acids in sunflower seeds in relation to genotype and water regime. Ital. J. Agron. 7: 3-14.

Schneiter AA, Miller JF, 1981. Description of sunflower growth stages. Crop Sci. 21: 901-903.

Sezen SM, Yazr A, Kapur B, Tekin S. 2011. Comparison of drip and sprinkler irrigation strategies on sunflower seed and oil yield and quality under Mediterranean climatic conditions. Agric. Water Manag. 98: 1153-1161.

Shabana R. 1974. Genetic variability of sunflower varieties and inbred lines, in: Proc. 6th Int. Sunf. Conf., Bucharest, Romania, pp. 263269.

Steer BT, Coaldrake PD, Pearson CJ, Canty CP. 1986. Effects of nitrogen supply and population density on plant development and yield components of irrigated sunflower (Helianthus annuus L.). Field Crops Res. 13: 99-115.

Tang S, León A, Bridges WC, Knapp SJ. 2006. Quantitative trait loci for genetically correlated seed traits are tightly linked to branching and pericarp pigment loci in sunflower. Crop. Sci. 46: 721734.

Tardieu F, Parent B, Caldeira CF, Welcker C. 2014. Genetic and physiological controls of growth under water deficit. Plant Physiol. 164: 1628-1635.

Thompson JA, Heenan DP. 1994. Effect of sowing time on growth, yield, and oil characteristics of irrigated sunflower in southern new-south-wales. Aust. J. Exp. Agric. 34: 255-258.

Tuck G, Glendininga MJ, Smith P, Housec JI, Wattenbach M. 2006. The potential distribution of bioenergy crops in Europe under present and future climate. Biomass Bioenergy 30: 183-197.

Unger PW. 1980. Planting date effects on growth, yield, and oil of irrigated sunflower. Agron. J. 72: 914-916.

Unger PW, Thompson TE. 1982. Planting date effects on sunflower head and seed development Agron. J. 74: 389-395.

Vear F, Bony H, Joubert G, Tourvieille de Labrouhe DT, Pauchet I, Pinochet X. 2003. 30 years of sunflower breeding in France. $O C L$ 10: 66-73.

Villalobos FJ, Hall AJ, Ritchie JT, Orgaz F. 1996. OILCROP-SUN: A development, growth, and yield model of the sunflower crop. Agron. J. 88: 403-415.

Zheljazkov VD, Vick BA, Baldwin BS, Buehring N, Astatkie T, Johnson B. 2009. Oil content and saturated fatty acids in sunflower as a function of planting date, nitrogen rate, and hybrid. Agron. J. 101: 1003-1011.

Zimmer DE, Zimmermann DC. 1972. Influence of some diseases on achene and oil quality of sunflower. Crop Sci. 12: 859-861.

Cite this article as: Fety Nambinina Andrianasolo, Philippe Debaeke, Luc Champolivier, Pierre Maury. Analysis and modelling of the factors controlling seed oil concentration in sunflower: a review. OCL 2016, 23(2) D206. 